\title{
JAVANESE GRADED READING BOOKS FOR ELEMENTARY SCHOOL STUDENTS
}

\author{
Supartinah, Sekar Purbarini Kawuryan, Woro Sri Hastuti \\ Faculty of Educational Science, Universitas Negeri Yogyakarta, Indonesia \\ Jalan Colombo Yogyakarta 55281, Indonesia \\ Corresponding Author: supartinah@uny.ac.id
}

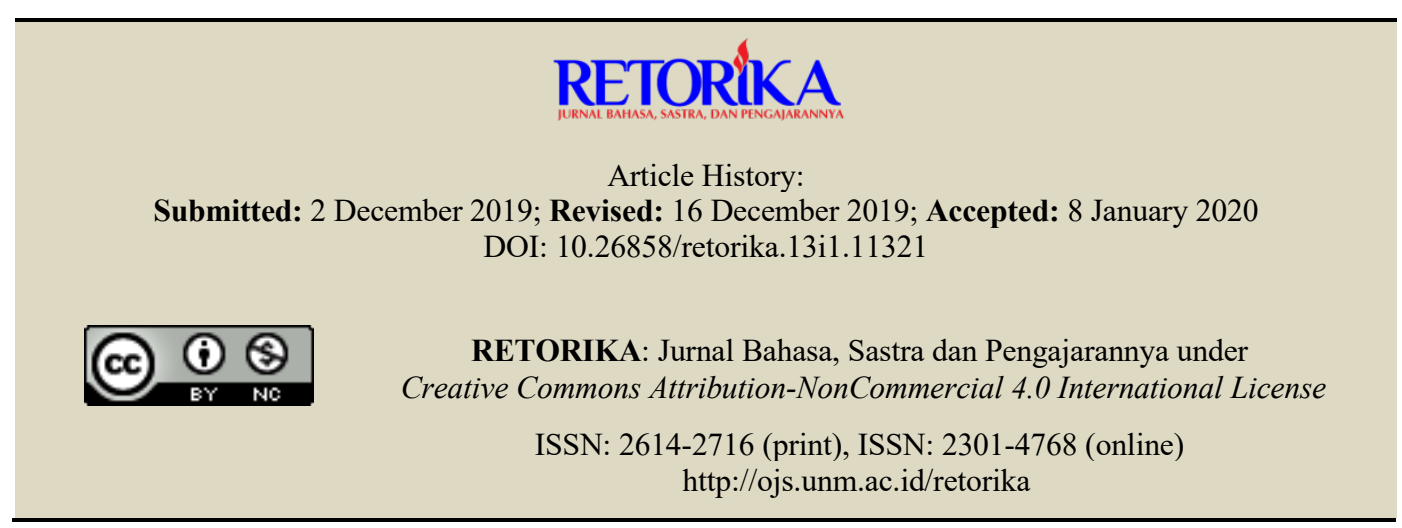

\begin{abstract}
This research was intended to develop graded readers (graded reading books) in the Javanese language for elementary school students. To develop the products, this work used the R\&D model by Borg and Gall, in which the main procedure was composed of product analysis, product development, expert validation, trials, and product revision. The subjects of this research were the elementary school students and the teachers of Bantul Regency, Sleman Regency, the City of Yogyakarta; experts in the Javanese language; experts in teaching and learning; and experts in teaching and learning media. The sample respondents were obtained through purposive sampling and the data were collected through questionnaires, observations, and interviews. The data were analyzed qualitatively and quantitatively. The products were validated by experts in learning contents, experts in teaching and learning, and experts in teaching and learning media. The result shows that they rated the products very good. The results of questionnaires distributed among the teachers and students show that these products carry positive impact on student learning. It can be concluded that the graded reading books are highly recommended for learning activities in elementary schools that offer Javanese.
\end{abstract}

Keywords: graded reading books, Javanese language, elementary schools

Literacy in the $21^{\text {st }}$ century requires multiliteracy competencies. Sang (2017) explained that changes in technology and social life have an impact on the demands for language skills to understand the new world. Radical changes in various aspects of human life need new literacy skills that are currently more complicated and diverse. Accordingly, Boche (2014) stated that the development of literacy competencies will be more diverse, dynamic, and flexible. Literacy continues to evolve and change, and consequent- ly teachers need to continuously implement literacy learning in classroom.

One of the competencies is reflected in one's reading skills. Reading skills are required to expand insights, knowledge, and experience; to improve thinking proficiency; to sharpen reasoning to achieve progress; and to develop the readership. The goal is that, eventually, students can ful-ly participate in the sociocultural activities of the world community. Mastering reading skills and making reading as a life necessity are 
urgent. The skills need to be provided since as early as I can. If reading skills in elementary schools are not adequately given, students may find it difficult to develop their knowledge and insights.

Good, Simmons, and Smith (1998) showed that slow readers when in the lower grade will experience more obstacles when in the higher level. This is also attested among elementary school students when studying the Javanese language. The reading skills are important to excellently read texts in Javanese, to understand the contents of Javanese language and culture.

There are elementary school students who have not been able to understand Javanese texts well. A preliminary study on the ability to read Javanese texts, especially in word-level reading among the elementary school students showed that as many as $44 \%$ of the lower grade still need guidance, $25 \%$ in the developing category, and $31 \%$ already in the independent category. Weaknesses in comprehending reading texts are still also found. As many as 33\% of them showed low ability in understanding the texts, $28 \%$ of them in the sufficient category, and 38\% already in the good category. As for reading comprehension, the scores of those in the continuing levels are not much different from those of the lower levels. As many as $35 \%$ of those in the continuing levels have not understood the contents of the texts, $37 \%$ quite good, and $28 \%$ already in the good category.

Reading ability for students of the lower levels refers to basic reading abilities to read texts written in Javanese scripts. Basic reading ability is necessary to help them become good readers. Teaching basic reading abilities is teaching the reading learning process to master the writing system as a visual representation of a language. This is called the level of learning to read. Dalman (2017) stated that teaching basic reading or reading techniques is necessary to train students to read with correct pronunciation and proper intonation. Therefore, reading aloud is an appropriate technique in basic reading.

An ability to distinguish sounds is also important to help understand that words are constructed from different sounds. The reading skills that should be taught include (a) how to use strategies to identify written words through sound connection or spelling and to know many words through seeing, (b) to use prior knowledge, vocabularies, and strategies to understand the contents of the reading materials, and (c) to develop fluency in basic literacy skills (Snow, Burns, and Griffin, 1998).

The ability to read obtained from basic reading will greatly affect the ability to read when in the advanced reading levels. Reading compre-hension in elementary schools is in fact part of advanced reading. At this level, students should understand the contents of the texts they read. The mastery of the skill is indicated in the ability to answer questions related to the reading or to retell the contents of the reading using their own sentences both orally and in writing.

Concerning this issue, Dalman (2017) stated that there are four levels of reading comprehension, namely literal comprehension, interpretive comprehension, critical comprehension, and creative comprehension. Good readers are those who accomplish the four levels.

Nurgiyantoro (2016) suggested that good reading ability and willingness to read are needed to achieve good reading proficiency. Interesting reading books can increase willingness or motivation to read. Wangid, Mustadi, and Putri (2018) reported that interesting math science fable books significantly improved the friendly character of grade 4 elementary school students. Integrating characters of fairy tales in science and mathematics teaching materials helps students understand texts with character education that suits their age.

Understanding the contents of texts is the main goal of reading activities. Tompkins (2010) said that people read to comprehend a text. Comprehension involves various levels of thought, from literal, inferential, critical, to the evaluative level of comprehension. Consequently, Javanese graded reading books which can accommodate the needs and abilities of students both at the basic and advanced levels in elementary school are highly needed.

Richards (2015) also stated that the use of graded readers or graded reading books which are developed on various levels of difficulties in terms of vocabulary, sentence length, sentence structure, and discourse features can be used to overcome the difficulties to understand various authentic texts. The texts can be some simplified versions of novels, the adaptation of other sources, or those written for special purpose including original fiction. Such texts help students develop reading fluency.

In addition, Harway and Young (2010) mentioned that books for children should meet some criteria. The criteria include the familiarity 
of the content with the background and knowledge of students, the language, the textual support, and the cultural conformity. The teaching materials have in fact include various cultural values (Nambiar, R.M.K., Hashim, R.S., \& Yasin, R.M., 2018; Hermawan \& Noerkhasanah 2012; Zakaria dan Hashim 2009; Abdullah \& Chandran, 2009).

Fountas and Pinnell (2008) explained some quite similar criteria of books for children, namely (a) the language should include the aspects of vocabulary, the text organization, the language style, and the prediction about the contents, (b) the format of the texts would include rules of print and illustration, and (c) the contents and concepts that cover the aspects of familiarity and the genre of the texts.

Based on the explanation above, this study aimed to develop Javanese graded reading books that can accommodate various reading abilities of elementary school students. In addition, it provided reading books in the Javanese language that have not been available for now. The books are expected to motivate and challenge students to read without frustration and boredom.

\section{METHOD}

This study employed a Research and Development (R\&D) of Borg and Gall (1989). The main procedure of this study covered (1) analyzing the product to be developed, (2) developing the product, (3) asking for expert validation, (4) piloting, and (5) revising the final product.

This research involved linguists, learning experts, and media experts for product validation. A Focus Group Discussion was done with 20 elementary school teachers of lower grades and advanced grades to provide an evaluation of the reading books. The revision of the books was then also based on the results of this activity, after which it was then piloted. The respondents in the trial stage were Grade I to Grade VI students of Golo Elementary School in Yogyakarta. The trial was to find out the responses of the students toward the Javanese graded reading books.

The samples were taken using a purposive sampling method. The data were collected through questionnaires, observations, and documenttations and were analyzed using quantitative and qualitative descriptive analyses. The scoring criteria for the results of the questionnaires by the expert and stakeholder refer to Mardapi (2008) as seen in table 1.

Based on table 1 above, the results can be explained as follows.

(1) The Very Good (A) category is for the score greater than 3.00 .

(2) The Good (B) category is for the score between 3.00 to greater than or the same as 2.50 .

(3) The Good Enough (C) category is for the score between 2.50 and greater than or the same as 2.00 .

(4) The Not Good Enough (D) category is for the score less than 2.00 .

Table 1. The Conversion of the Quantitative Data

\begin{tabular}{|c|c|c|c|}
\hline No. & Rentang Skor & Nilai & Kategori \\
\hline 1. & $\mathrm{X} \geq \overline{\mathrm{X}}+1 . \mathrm{SBx}$ & $\mathrm{A}$ & Very Good \\
\hline 2. & $\overline{\mathrm{X}}+1 . \mathrm{SBx}>\mathrm{X} \geq \overline{\mathrm{X}}$ & B & Good \\
\hline 3. & $\overline{\mathrm{X}}>\mathrm{X} \geq \overline{\mathrm{X}}-1 . \mathrm{SBx}$ & $\mathrm{C}$ & Enough \\
\hline 4. & $\mathrm{X}<\overline{\mathrm{X}}-1 . \mathrm{SBx}$ & $\mathrm{D}$ & Less \\
\hline \multicolumn{4}{|c|}{ Note: } \\
\hline$\overline{\mathrm{X}}$ & : mean score & & \\
\hline SBx & : the standard der & ition & \\
\hline $\mathrm{X}$ & : the score achiev & & \\
\hline
\end{tabular}

\section{FINDINGS AND DISCUSSION}

\section{Findings}

\section{Developing Javanese Graded Reading Books}

The products developed in this research are Javanese graded readers or graded reading books in the Javanese language meant for elementary school students. The books contain local wisdoms as stated in the basic competencies of Javanese language subjects. The development of the books is adjusted to the required contents. As for the technical presentation, it was written specificalty for elementary schoolers.

The texts used Andika New Basic font. This type of font is chosen to help especially the lower level students to be able to read the texts. In addition, this font is easy to recognize and remember because of its simple form. The size of the paper is $20 \times 20 \mathrm{~cm}$. This size is opted so that the students can easily hold it. The size of the illustrations and the fonts will enable the students to read the texts better. The paper is 230 ivory for the cover and 150 art paper for the contents. This is chosen because of its endurance considering that the users 
are young elementary school students. The bright and soft colors are selected to make the books in- teresting. The nine Javanese graded reading books produced in this research are presented in table 2 .

Table 2. Description of The Javanese Graded Reading Books

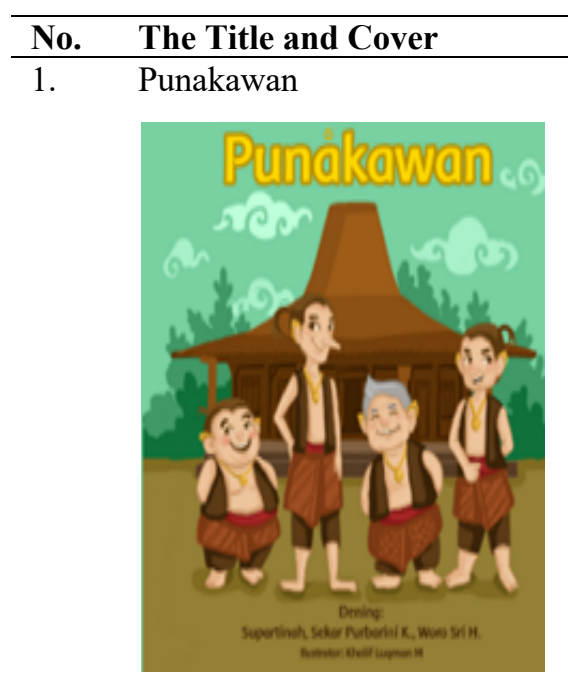

2. $\quad$ Adhikku Lucu

(My Adorable Sister)

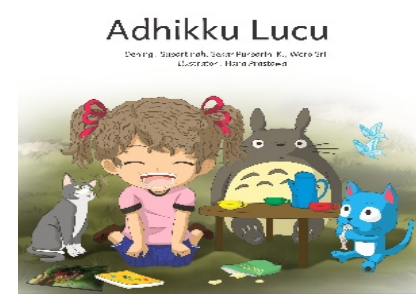

The Contents

This reading book is intended for students of the lower grade, especially those in the first grade. The title of this book is Punakawan. This book can be used for students who first learn to read. The texts are presented in 1-2 sentences per page with a large size accompanied with illustrations. The texts are fewer than the illustrations. The illustrations are more dominant on each page. Some texts are connected on two pages. There are repetitions of words per page and across pages, highlights of the use of letter sounds through the use of diacritical signs such as $\dot{e}, \dot{e}$, $\hat{e}, \stackrel{a}{a}$, and short and simple sentences. The language variety used is $\mathrm{Kra}-$ ma Lugu. The content of this book is delivered with simple, informative, and descriptive texts that tell a story about Punakawan. The title is the name of the family of Father Semar and his 3 sons. Gareng is the first child with his helpful character; Petruk the second child has a clever speaking character; and Bagong the third child has a funny character. Father Semar has a wise character. The Punakawanis a family with noble characters.

This reading book of Adhikku Lucu (My Adorable Sister) is still meant for the same level as the previous book, but with thematic stories. This book is written for the basic level students who first learn to read. This is still presented with large and clear illustrations and designed to build interest in learning to read. The Javanese language variety used is Ngoko Lugu. The story is delivered in the form of a simple, predictable, informative, and descriptive text. The character of education developed in this story is about values of affection towards family members. In short, this book tells a story about love for a cute, adorable, and chubby sister who still likes to wet the bed but is never fussy.

3. Kanca Sekolah (My Schoolmates)

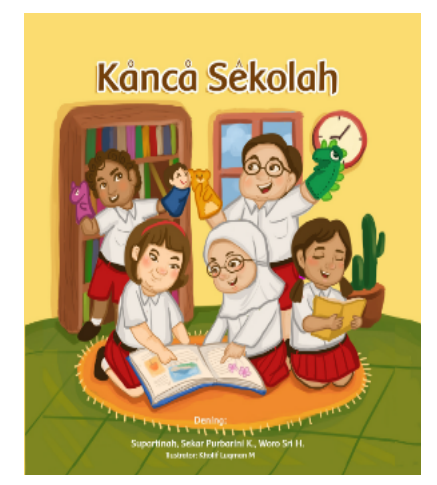

This graded reading book is also prepared for the basic levels, especially for students of grade I, those who are in the ending phase of the level/class. The amount of text is less than the illustration on each page of two connected pages. Each page only contains 2-3 sentences, and some words are repeated. The diacritical marks to reinforce differences in sound and allophones are also maintained. Simple sentences with punctuation and rhyming word are used. The vocabularies are those of everyday life. The illustrations are presented in large size, are dominant and clear, and illustrate the idea of the story. The story is simple and based on events and children's experiences. The Javanese language variety in this book is Krama. This book tells about a child named Jani, a grade 1 student who shows a courtesy and respect for parents and teachers. Jani likes hanging out. She has many friends. Jani gets along well with her friends although they have different interests.
Dolanan Bareng Kanca
(Playing with Friends)
This book is intended for those in basic level, especially the beginning phase of grade II. There are 3-4 sentences on each page equipped with diacritical signs and new level-3 vocabularies. The story and illustrations are designed to build contexts and interest in reading. The illustrations and characters should help students understand the content of the story. The Javanese language variety used is Ngoko. This story is descriptive realistic which tells about Budi and his friends who perform various traditional games on their vacation with joy, harmony, and sportsman- 


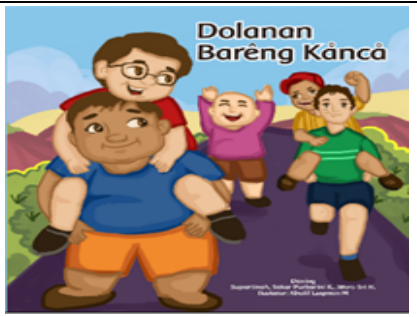

ship. The traditional games played were cublak suweng, kothekan, benthik, ki lumpang ki lompong, kubuk, and kauman.

5. Dolanan Dhakon

(Playing Dhakon)

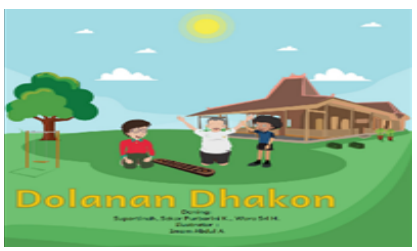

This graded reading book is for grade II students of the ending phase of the class. There are 4-5 sentences on each page. The amount of illustration and the text is similar. The story is written in a simple and straightforward storyline. The Javanese language variety used is Ngoko. This book is about three brothers, namely Rafa, Kaka, and Satya who are playing a traditional Javanese game, dhakon. They play the game happily. The game is over when the call for prayer is heard. They then go to the mosque to pray.

6. Tiba Kepleset

(Slipping Over)

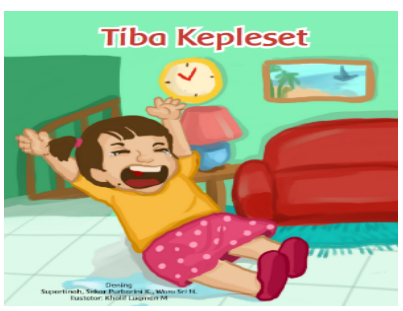

This graded reading book is prepared for grade III students with 4-8 sentences on each page. The amount of the text and illustration is balanced on each page. The text is presented without diacritical marks. There are several compound sentences, and it uses quoted speech or dialogues. The illustrations in this book are made medium-sized, quite complex, and detailed. The content of the story is realistic with double topics describing and showing cause and effect. The Javanese language used is Ngoko. This book is about Bisma's family who live in a safe and comfortable village. This family likes cooperation, helping each other, clean environment, and discussing to solve problems.
7. Bagas Si Kethek Cilik (Bagas the Little Monkey)

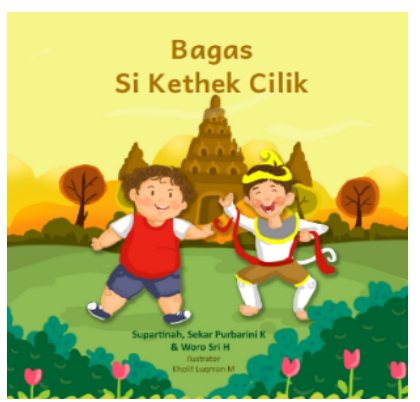

This graded reading book is intended for the advanced level of elementary school students with 8-10 sentences on each page. Texts are more dominant than pictures. This book introduces new vocabularies and loan words on each page without repeating the previous words entries. Both compound and complex sentences are introduced in this book. The illustration does not fully describe the background, events, and characters because the story on each page is more complex. The content of the story is realistic with double topics that describe, compare, show cause and effect, and expose problems and solutions. The Javanese language varieties used are Ngoko and Krama. This book narrates Wisnu's experience with his new friend, Bagas, a Hanuman dancer in the Ramayana performance. From the friendship, Wisnu gains experience about courage and care.
8. Gara-gara Selfi (Because of Selfie)

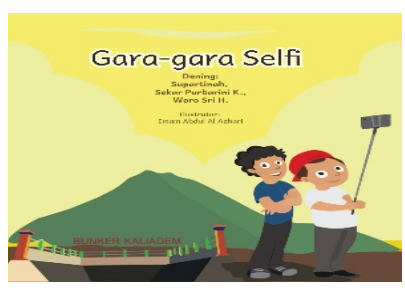

9. $\quad$ Kluwung ing Wektu Grimis (A Rainbow in the Drizzle)
This book is also for the advanced grade. Each sentence has 8-15 words, and each page has 8-10 sentences. The texts are more dominant than the pictures. This book is about naughty Reno, an elementary school student. On a trip to Merapi, Reno makes a prank to his friends. He is not disciplined and is always busy with his gadget. Finally, Reno is left behind from the group. The unpleasant experience provides a valuable experience that makes him aware of his bad attitude. It makes him promise to become a better child.

This last level is also for advanced students. Each sentence is composed of more than 15 words, and each page has 8-10 sentences. The texts use standard font size. The texts on each page are more dominant than the illustrations. This is a fantasy story with a more complex storyline and a 


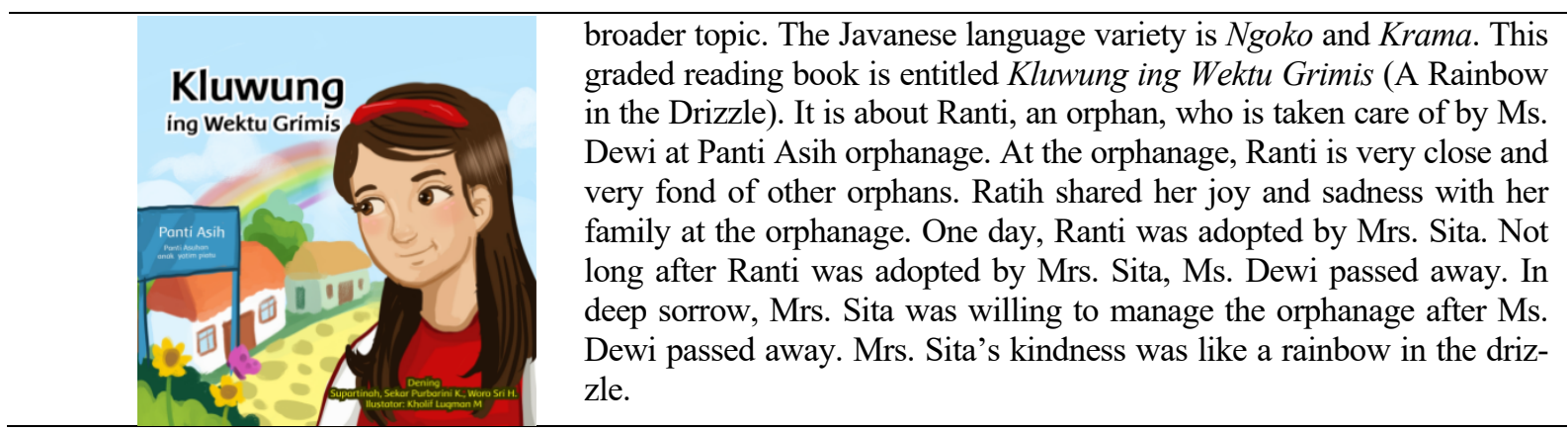

These Javanese graded readers are equipped with a glossary to help students understand difficult vocabularies. In addition, there are questions about the contents to practice telling the message of the texts in Javanese. Teachers can also use them to check students' understanding.

\section{Product Validation}

The product validation through product assessment was carried out by linguists in the Javanese language, experts in teaching and learning, and experts in teaching and learning media. The book was validated based on the theoretical and methodological aspects.

The assessment on the aspect of the Javanese language is focused on the use of a variety of styles in the Javanese language, the linguistic aspects in students' reading competencies, contents, the local wisdom, the focus on positive characters, the characteristics of elementary school students, and the adequacy of illustrations. The assessment on the aspect of learning is focused on the conformity with the principles of learning, the richness of the substance, the capability of the books for group and individual assignments, the meaningfulness of learning experience, the creation of multidirectional communication, the selfevaluation, and the facilitation of knowledge.

The product assessment on the aspect of learning media is emphasized on the aspect of conformity with the learning objectives, the students' reading ability, the layout elements, the attractiveness of illustrations, the book size, the font size, the effectiveness of production, and the book materials. It also was also aimed to promote the motivation to read and to train students to remember information. The assessment of the Javanese graded reading books was carried out in 2 stages. The results of the assessment were categorized into 4 scales. The first stage of the assessment is presented in Table 3.

The books received feedback for improvement from the Javanese linguists. The input was about the consistency of the diacritic symbols to distinguish vowels in the Javanese language and the provision of a glossary of unfamiliar Javanese vocabularies.

Table 3. Results of Validation

\begin{tabular}{lcc}
\hline \multicolumn{1}{c}{ Experts } & Results & Categories \\
\hline Javanese Language & 2.9 & Good \\
Teaching \& Learning & 3 & Good \\
$\begin{array}{l}\text { Teaching \& Learning } \\
\text { Media }\end{array}$ & 2.6 & Good \\
\end{tabular}

The input from the learning experts was about the need to provide questions for students and to attend each student's needs to establish multidirectional communication among the readers. The input from the learning media experts was that the illustrations are too large, and that sufficient free space is needed so that the book does not look too crowded. The results of the product evaluation after some revisions are as follows.

Table 4. Results of Stage II Expert Validation

\begin{tabular}{lcc}
\hline \multicolumn{1}{c}{ Experts } & Results & Criteria \\
\hline Javanese Language & 3.8 & Very Good \\
Teaching \& Learning & 3.4 & Very Good \\
$\begin{array}{l}\text { Teaching \& Learning } \\
\text { Media }\end{array}$ & 3.9 & Very Good \\
\hline
\end{tabular}

Based on the feedback from the Javanese linguists, experts in teaching and learning, and experts in teaching and learning media, it can be reported that principally, these books are suitable for learning the Javanese language in elementary schools.

Likewise, the evaluation by the teachers shows very good results with an average score of 3.46 on a scale of 4 . The conformity with the learning objectives, the capacity to accommodate students' reading ability, the content of local wis- 
dom, the positive character development, the capacity to stimulate reading interest, the capacity of the content to motivate students, the capacity to create reading for pleasure, the capability to understand and remember information, the element of layout, the conformity with the environment, the book size, the font size, and the size and support of the illustrations were all rated highly. The results are presented below.

\section{The Results from the Try-outs}

The trial was intended to find out the responses of the students, the readability, and the level of comprehension of the book. The graded reading books were prepared to facilitate a wide range of reading abilities and reading needs of students. The trial was conducted at Golo Elementary School with 18 students of grades I, II, III, IV, $\mathrm{V}$, and VI with diverse reading abilities, namely needing guidance category, developing category, and independent category. The responses of the students to the reading books showed an average score of 3.03, which fell within the good category. The questionnaires emphasized on the statements about reading comprehension, book attractiveness, exemplary character, capability to motivate, ease of comprehension, illustration to help understand the stories, illustration attractiveness, and book size. The results are presented in table 6 . The results of questionnaires from the students show various positive responses about the books.

Table 5. Results of Teachers' Assessment

\begin{tabular}{|c|c|c|c|}
\hline No. & Aspects & Average & Categories \\
\hline 1. & The conformity with the purpose of Javanese language learning & 3.4 & Very Good \\
\hline 2. & The capability to accommodate students' reading ability & 3.2 & Very Good \\
\hline 3. & The usefulness of the content of local wisdom in the texts & 3.65 & Very Good \\
\hline 4. & The usefulness to develop positive characters & 3.5 & Very Good \\
\hline 5. & The potential to stimulate students' interest in reading & 3.5 & Very Good \\
\hline 6. & The capacity to motivate students to read & 3.5 & Very Good \\
\hline 7. & The capacity to create pleasure & 3.35 & Very Good \\
\hline 8. & The capacity help understand and remember information & 3.5 & Very Good \\
\hline 9. & The clarity of layout elements & 3.5 & Very Good \\
\hline 10. & The suitability of the reading materials with students' real life & 3.45 & Very Good \\
\hline 11. & The book size & 3.45 & Very Good \\
\hline 12. & The font size & 3.6 & Very Good \\
\hline 13. & The size of the illustrations & 3.45 & Very Good \\
\hline 14. & The capacity of the illustrations to support the content & 3.4 & Very Good \\
\hline \multicolumn{2}{|c|}{ Total } & \multicolumn{2}{|c|}{3.46} \\
\hline \multicolumn{2}{|c|}{ Category } & \multicolumn{2}{|c|}{ Very Good } \\
\hline
\end{tabular}

Table 6. Results of Students Responses

\begin{tabular}{clcc}
\hline No. & \multicolumn{1}{c}{ Aspects } & Average & Categories \\
\hline 1. & Levels of comprehension of the content & 2.78 & Good \\
2. & Curiosity over the content & 3.06 & Good \\
3. & Their level of interest & 3.22 & Very Good \\
4. & Positive attitudes that can be imitated & 3.11 & Very Good \\
5. & Ability to retell the content & 2.78 & Good \\
6. & The absence of difficult words & 2.78 & Good \\
7. & Ease of comprehending the sentences & 2.94 & Good \\
8. & Illustration to help understand the content & 3.17 & Very Good \\
9. & Interesting illustration & 3.33 & Very Good \\
10 & Text and illustration size & 3.17 & Very Good \\
\hline \multicolumn{5}{r}{ Total } & 3.03 & \\
\hline
\end{tabular}




\section{Discussion}

Students in elementary schools show different reading proficiency in the Javanese language. In fact, they have not showed the same level of reading skills. In this regard, Musfiroh and Listyorini (2016) said that reading literacy competence is the ability to read texts based on the cognitive level (normal graphics) and text types in local and national contexts.

The books in this R\&D work provide different levels of difficulty. Some texts are easy to read for some students but not for others. The range of difficulty is designed to provide students with diverse abilities and needs.

About this topic, Ulusoy (2006) suggested that finding both easy and difficult texts to meet students' abilities and needs of reading is important. A properly written reading book can help improve students' literacy skills. Similarly, stated that choosing a suitable reading book is not easy. This is because students have their types of books and their favorite authors. They have reasons why they enjoy the books they have read.

The contents of these books have been adapted to the contents of Javanese language learning materials in elementary schools at every level of the grades. This is based on the Javanese language curriculum for the basic education level of 2013. The content of the stories is presented from simple to complex. Related to this matter, Abidin, Mulyati, and Yunansah (2017) stated that learning is successful if the learning materials are designed in accordance with learners' learning abilities. These books should meet the demands for Javanese language reading materials that cater to the needs of diverse abilities of elementary school students. Dewayani (2017) said that in fact, current reading books for students in schools have not carried suitable texts for children. The texts are mostly written in various types of texts that do not the capacity to build students as lifelong learners.

These books provide visual displays or illustrations on each page. This does not only increase the motivation but also help comprehend the contents of the texts. Many studies have proven the relation between reading skills and visual perception (Çayir, 2017; Kavale and Forness, 2000; Memis and Sivri, 2016).

Elementary school students are at the stage of concrete, operational, and intellectual development at which children begin to think, to know the relationship between logical impressions, and to make decisions about what is connected logically
(Santrock, 2009: 42). The stories presented in the books are related closely with the daily life of the children. This way, it should help students to associate stories in books with their real life experiences. The findings of a research by Muhammadi, Taufina, and Chandra (2018) showed that folklores of the archipelago can be used to build social attitudes and love towards the cultures.

These books support the development of students' reading skills, especially to understand the Javanese information sources. This is one way to develop literacy skills to help interact and communicate with the community. Ali, Karim, and Yusof (2016) stated that literacy is related to the capabilities to identify, understand, interpret, create, and communicate using oral and written forms in various contexts to develop knowledge and potentials in participating and interacting in the community.

With the literacy skills in the context of Javanese culture, students are expected to be able to easily interact and communicate with the community, especially with the people of Yogyakarta. For that reason, the books also provide support for the Government of the Special the Yogyakarta Special Region on the Management and Implementation of Culture-Based Education. The teaching and use of the Javanese language has in fact been regulated in the Provincial Regulation of the Special Region of Yogyakarta number 5 of 2011.

The local wisdom content is provided to improve knowledge, skills, and attitudes of the students so that they have extensive knowledge about local values or rules that apply in their area and support the preservation of regional development and national development (Saputra, 2013). The Javanese language as a mandatory local content for elementary schools is one of the government's efforts to maintain Javanese local wisdoms.

One of the local wisdoms introduced in the books is represented through the puppet story of punakawan. Puppets, according to Soesilo (2004), mean shadows or shade or pratiwimba, one traditional Indonesian traditional classic cultural art that is rich in messages. The characters are introduced and written in a simple but interesting way. Punakawan are humorous characters. Punakawan consists of four unique characters: Semar, Petruk, Gareng, and Bagong. Semar is wise and rich with knowledge and has contributed a lot to the leaders through his advice. Meanwhile, Gareng is not very fluent in speaking, but actually extraordinarily clever. Petruk is an ordinary character who is good at 
speaking. The last figure, Bagong, is smart in conveying criticisms through the jokes he makes.

These Javanese cultural wisdoms underlie the cultural values that apply to the people of Yogyakarta. Ghufron, Budiningsih, and Hidayati (2017) suggested that learning Yogyakarta cultural values is a learning activity to facilitate students to master skills about values that apply in Yogyakarta. The provision of basic literacy skills based on the cultural values is not only the responsibility of the schools but also the task of families at home. Curry, Reeves, and Mcintyre (2016) opinioned that it is important for schools and families to work together to provide comprehensive and consistent literacy learning experience for students. These Javanese graded readers/reading books allow parents to provide assistance to students' reading at home. To support the mentoring activity, the graded reading books are provided with a glossary, tegesing tembung (word meaning), at the end of the books. This glossary contains a list of meanings of certain Javanese words that the students may not yet be familiar with. Students can do reading activities with their family at home. This can definitely not only develop students' ability to read but also add information, build reading habit, and make students familiar with reading for pleasure. The role of the family is deemed important to help build readership (Morrow 1985; Gove and Cvelich 2010; Johari, Tom, Morni \& Sahari 2013).

\section{REFERENCES}

Abdullah, N., \& Chandran, S. K. (2009). Cultural elements in a Malaysian. English language textbook. [Online]. Available at ddms.usim.edu. my/ bitstream/handle [10 September 2010].

Abidin, Y., Mulyati, T., \& Yunansah, H. (2017). Developing literacy learning model based on multiliteracy, integrated, and differentiated concept at elementary school. Cakrawala Pendidikan, 36 (2), 156-166.

Ali, R. M., Karim, H. B. B. A, \& Yusof, F. M. (2016). Experienced elementary school teachers' thoughts on effective teachers of literacy and numeracy. Malaysian Journal of Learning and Instruction, (13), 43-62.

Boche, B. (2014). Multiliteracies in the classroom: Emerging conceptions of first-year teachers. Journal of Language \& Literacy Education [Online], 1 (10), 114-135. Retrieved from http://jolle.coe.uga.edu.

\section{CONCLUSION}

These Javanese graded reading books have been validated by the content experts, experts in teaching and learning, and experts in teaching and learning media. Their evaluation shows that the books are very good and the same is stated by the teachers and the students themselves. This shows that the books are suitable for Javanese language learning in elementary schools. These books should meet the needs for reading texts that can accommodate diverse students' reading abilities. They are reading materials that have not been available until today.

\section{ACKNOWLEDGEMENTS}

This report is written based on research about Developing Local Wisdom Based Graded Reading Books as Character Education Internalization Media to Learn the Javanese Language in Elementary Schools. The writers would like to thank the Director of Research and Community Service of the Directorate General of Research Strengthening and Development of the Ministry of Research, Technology, and Higher Education who has funded this project.

Borg, R.W., \& Gall, M. (1989). Educational research: An introduction third edition. New York: Longman.

Çayir, A. (2017). Analyzing the reading skills and visual perception levels of first grade students. Universal Journal of Educational Research, 5 (7), 1114 1116, doi: 10.13189/ujer.2017.050704.

Curry, D. L., Reeves, E., \& McIntyre, C.J. (2016). Connecting schools and families: Understanding the influence of home literacy practices. Texas Journal of Literacy Education, 2(4), 69-77.

Dalman. (2017). Keterampilan membaca. Jakarta: Raja Grafindo Persada.

Dewayani, S. (2017). Menghidupkan literasi di ruang kelas. Yogyakarta: Kanisius.

Fountas, I.C. \& Pinnell, G.S. (2008). The continuum of literacy learning grades pre-K-8: A guide to teaching. Portsmouth, NH: Heinemann.

Ghufron, A., Budiningsih, C. A., \& Hidayati. (2017). Pengembangan pembelajaran berbasis nilai-nilai 
budaya Yogyakarta di sekolah dasar. Cakrawala Pendidikan, 2 (36), 309-319.

Good, R.H., Simmons, D.C., \& Smith, S.B. (1998). Effective academic interventions in the United States: Evaluating and enchancing the acquisition of early reading skills. School Psychology Review, 27, 740-753. (Education and Child Psychology)

Gove, A. \& Cvelich, P. (2010). Early reading: Igniting education for all. A report by the early grade learning community of practice. Retrieved on March, 12, 2012 from http://www.uis.unesco .org/Education/Documents/early-readingreport gove cvelich.pdf.

Hermawan, B., \& Noerkhasanah, L. (2012). Traces of cultures in English textbooks for primary education. Indonesian Journal of Applied Linguistics, 1 (2), 49-61.

Johari, A., Tom, A.A., Morni, A., Sahari, S. H., (2013). Students reading practices and environments. Indonesian Journal of Applied Linguistics, 3(1), 17-28.

Kavale, K., \& Forness, S. (2000). Auditory and visual perception processes and reading ability: A quantitative reanalysis and historical reinterpretation. Learning Disability Quarterly, 23, 253-270, doi: $10.2307 / 1511348$.

Mardapi, D. (2008). Teknik penyusunan instrumen tes dan nontes. Yogyakarta: Mitra Cendekia Press.

Memiş, A., \& Sivri, D. (2016). The analysis of reading skills and visual perception levels of first grade Turkish students. Journal of education and training studies, 8(4), 161-166, doi:10.11114/ jets.v4i8.1663.

Morrow, L. M. (1986). Developing young voluntary readers: The home-the child-the school. Reading research and instruction, 25(1), 1-8, doi: 10.1080/19388078509557853.

Muhammadi, Taufina, \& Candra. (2018). Literasi membaca untuk memantapkan nilai sosial siswa sd. Jurnal LITERA, 2(17), 202-212.

Musfiroh, T., \& Listyorini, B. (2016). Konstruk kompetensi literasi untuk siswa sekolah dasar. Jurnal LITERA, 1(15), 1-12.

Nambiar, R. M. K., Hashim, R. S., Yasin, R. M. (2018). Impact of integrating local culture into language materials on communicative ability of Malaysian lower secondary learners. $3 L$ : The
Southeast Asian Journal of English Language Studies, 24(4), 13-26, doi: 10.17576/3L-20182404-02.

Nurgiyantoro, B. (2016). Penilaian pembelajaran bahasa berbasis kompetensi. Yogyakarta: BPFE.

Peraturan Pemerintah Daerah Istimewa Yogyakarta Nomor 5 Tahun 2011 tentang Pengelolaan dan Penyelenggaraan Pendidikan Berbasis Budaya.

Richards, J.C. (2015). Key issues in language teaching. United Kingdom: Cambridge University Press.

Sang, Y. (2017). Expanded territories of "literacy": New literacies and multiliteracies. Journal of Education and Practice, 8 (8), 16-19. ISSN 2222-288X [Online].

Santrock, J. W. (2009). Educational psychology. (Diana Angelica, Trans). Jakarta: Salemba $\mathrm{Hu}-$ manika. (Original work published 2008).

Saputra, G. A. S. (2013). Enhancing local wisdom throuh local content of elementary school in $\mathrm{Ja}$ $v a$, Indonesia. Proceeding of the Global Summit on Education. (E-ISBN978-967-11768-01)Organized by WorldConferences.net 614.

Snow, C. E., Burns, M. S., \& Griffin, P. (Eds.). (1998). Preventing reading difficulties in young children. Washington, DC: The National Academy Press.

Soesilo. (2004). Kejawen, philosofi dan perilaku. Yogyakarta: Pustaka Jogja Mandiri.

Tompkins, E.G., \&Hoskisson, K. (1995). Language arts: Content and teaching strategies. New Jersey: Prentice-Hall.

Tompkins, G. E. (2010). Literacy for the 21st century a balanced approach. Boston: Allyn \& Bacon/ Pearson.

Ulusoy, M. (2006). Readability approaches: Implications for Turkey. International Education Journal, 7(3), 323-332. http://iej.com.au.

Wangid, M. N., Mustadi, A., \& Putri A. R. (2018). Fairy story integration for meaningful classroom. Jurnal Cakrawala Pendidikan, 2 (37), 165.

Zakaria, M. H., \& Hashim, H. M. (2009). Local cultural aspects in the KBSM English language materials. Faculty of Education, Universiti Teknologi Malaysia. 